\title{
Caminhos percorridos pelo dr. Jorge Clarke Bleyer nos campos da medicina tropical e da pré-história brasileira
}

\author{
Paths taken by Dr. Jorge Clarke \\ Bleyer in the fields of tropical \\ medicine and Brazilian prebistory.
}

Terezinha de Jesus Thibes Bleyer Martins Costa

SHIS QI 11 Conjunto 8 Casa 24

71625-280 Brasília - DF Brasil

\begin{abstract}
Esta nota de pesquisa apresenta uma avaliação preliminar da trajetória de Georg Carl Adolf Bleyer, médico, higienista e naturalista que desempenhou papel crucial na instituição da saúde pública em Santa Catarina, e que foi um dos pioneiros da medicina tropical, da antropologia e da arqueologia no Brasil. Adolpho Lutz foi um dos principais interlocutores, no Brasil, desse médico igualmente polivalente que publicou importantes trabalhos em periódicos alemães. O estudo mais aprofundado de sua trajetória, além de ser importante para a história das mencionadas disciplinas, permite conhecer as condições em que eram exercidas as práticas médica e científica em cenários periféricos aos grandes centros urbanos do Sudeste do Brasil, que dominam a historiografia da medicina e das ciências.
\end{abstract}

PALAVRAS-CHAVE: Georg Carl Adolf Bleyer, medicina tropical, história da saúde pública, índios do Brasil, história da microbiologia.

This research note presents a preliminary evaluation of the life history of Georg Carl Adolf Bleyer, physician, hygienist and naturalist who played a crucial role in the institution of public health in Santa Catarina and was a pioneer in tropical medicine, anthropology and archeology of Brazil. Adolpho Lutz was one of the main partners in Brazil of this equally multifaceted physician who published important articles in German journals. His most thorough study was important to the history of the disciplines with which he worked; it provides the basis for understanding the conditions of medical and scientific practice in places far from the urban centers of southeastern Brazil that dominate the historiography of medicine and science.

KEYWORDS: Georg Carl Adolf Bleyer; tropical medicine; history of public health; indians of Brazil; history of microbiology.

\footnotetext{
Corg Carl Adolf Bleyer, médico, higienista e naturalista, nasceu $\checkmark$ em Hannover, a 21 de janeiro de 1867, filho de Friedrich Karl Cristoph Caspar Bleyer (1835), alemão de Linden, e Carolyn Amalie Clarke (1836), nascida em Manchester (Inglaterra). À época, Pasteur começava a descortinar o mundo dos micróbios e parasitas, toxinas e antitoxinas, vacinas e soros associados à promessa de novos horizontes para a humanidade.
} 
Devido às funções que o pai exercia junto à Superintendência da Casa Real de Hannover, Georg teve uma educação privilegiada. Freqüentou o 1을 Gymnasium Real $\mathrm{Zu}$ Hannover e a Koeniglichen Technischen Hochschule Zu Hannover, onde se diplomou em ciências naturais, em 1888. À esmerada formação aliava a capacidade de falar e escrever com fluência alemão, inglês, francês, italiano, grego e latim; a esse rol logo acrescentaria também o português.

Bleyer cursou medicina em Londres, no University College, onde recebeu o título de doutor em 15 de outubro de 1891, ao defender cum laude tese intitulada 'Sclange Faune Den Tschland, Eine Schilderung der im Ellittempa Lelunden' (Fauna ofídica da Alemanha: uma descrição das Ellittempa Lelunden). Esse estudo valeu-lhe a indicação para integrar a congregação dos lentes daquela universidade, mas Bleyer não aceitou a honraria. Queria viajar, conhecer novas terras, realizar investigações de campo nos domínios da história natural, bacteriologia e antropologia, ciências que o fascinavam. Seu gosto pelas expedições científicas foi estimulado pelos livros em que Karl von den Steinen (1885-1929), antropólogo de renome internacional e professor da Universidade de Berlim, descrevia suas expedições ao Brasil, em 1884 e 1889, inclusive a permanência entre tribos selvagens do Xingu. Das expedições de Steinen participaram o naturalista Fritz Müller, o engenheiro Emilio Oderbrecht, assim como os drs. Paulo Ehrenreich e Vogel, co-autores de obras sobre aspectos antropológicos, médicos e geográficos da região do Mato Grosso. Em seu livro, Steinen narrou a viagem ao estado de Santa Catarina, em 1889, onde percorreu a ilha do mesmo nome e, no continente, Laguna, o município de Orleães e as serras limítrofes com São Joaquim. Steinen levou material abundante de estudo para o Museu Etnográfico e para a Universidade de Berlim. ${ }^{1}$

Bleyer leu com entusiasmo suas narrativas, e ganhou de presente de formatura uma viagem à Índia e à América do Sul. Descreveu os dias intermináveis navegando sobre o mar dos Sargaços, e a beleza das algas multicelulares que observou aí. Ao chegar ao Brasil, em 1892, Bleyer refez o trajeto de Steinen e acabou se fixando em Blumenau, localidade catarinense onde viviam seus compatriotas e o notável Fritz Müller. Sua chegada àquela vila, onde quase não havia

\footnotetext{
${ }^{1} \mathrm{O}$ relato da primeira expedição de Steinen consta em Durch Central-Brasilien. Expedition zur erforschung des Schingú im jabre 1884. Von Karl von den Steinen. Mit über 100 text- und separatbildern von Wilhelm von den Steinen, 12 separatbildern von Johannes Gehrts, einer specialkarte des Schingústroms von Otto Clauss, einer ethnographischen kartenskizze und einer übersichtskarte. Leipzig, F. A. Brockhaus, 1886. Há uma tradução brasileira feita por Catarina Baratz Cannabrava (Steinen, 1942). A segunda expedição deu origem a Unter den naturvölkern Zentral-Brasiliens. Reiseschilderung und ergebnisse der zweiten Schingú-expedition, 1887-1888, von Karl von den Steinen Mit 30 tafeln (1 beliogravïre, 11 lichtdruckbilder, 5 autotypien und 7 lithogr. tafeln), sowie 160 text-abbildungen nach den photographien der expedition, nach den originalaufnabmen von Wilhelm von den Steinen und nach zeichnungen von Johannes Gehrts nebst einer karte von prof. dr. Peter Vogel. Berlim, D. Reimer (Hoefer \& Vohsen), 1894. Foi traduzido por Egon Schaden (Steinen, 1940).
} 
médicos, foi providencial e ele logo começou a trabalhar no hospital local e em povoados próximos. O trabalho era intenso, e as condições de vida muito diferentes daquelas da Europa, a que estava acostumado. Enfrentava toda sorte de dificuldades para assistir os doentes moradores na zona rural. Como era costume naquela época, um cliente mandou publicar no jornal uma nota de gratidão ao médico, transcrita, em parte, a seguir:

Enfermos: eu, minha mulher e duas filhinhas, acometidos por gravíssimas e diferentes moléstias, à clarividência e inimitável dedicação do caridoso médico, valeram-nos (a nós e a ele), o triunfo completo nessa ingente luta, sem tréguas, travada há tantos meses.

Quantas vezes em noites frias e chuvosas o bom amigo fez o percurso de uma légua, ou mais, da cidade à minha habitação, sem nunca se mostrar constrangido ou fatigado, passando vigilante essas mesmas noites em busca de alívio aos seus doentes, isto é, a mim e àqueles que me são caros? Quantas? (O Imparcial, 11.9.1901)

Herdeiro dos ideais do romantismo alemão (1797-1815), que Alexander Humboldt personificara como ninguém, e, ao mesmo tempo, protestante evangélico com sólida formação religiosa, Bleyer era um jovem que aliava a bondade à aspiração de realizar grandes feitos em prol da ciência e da humanidade.

Ao visitar um doente em estado grave em Lajes (SC), conheceu Adelaide Augusta Neves, e com ela se casou em 1898. Apesar de não ser formada em enfermagem, tornou-se sua auxiliar onde quer que fosse chamado, pouco importando os desconfortos das mudanças ou os solavancos das estradas precárias. O casal residiu em diversos municípios e, por esse motivo, seus 11 filhos nasceram em diferentes localidades.

As atividades de Bleyer não se limitaram ao exercício da clínica no hospital e à beira do leito dos doentes. Destacou-se, também, como principal defensor da higiene pública no estado, e publicou diversos trabalhos sobre medicina, zoologia, etnografia e arqueologia em revistas científicas européias, sobretudo da Alemanha. Tratou, por exemplo, de "uma larva de Cuterebra na pálpebra" (1900); "uma mulher adoecida com ictiofagia" (1902), da "toxidez da Cuatiara" (1903), das "urtigas brasileiras e uma urticária causada por elas" (1909), de "um estranho tratamento índio de um caso de tireoidite parasitária" (1923). $\mathrm{Na}$ vila onde residia, e nos sítios e fazendas que visitava, procurava ensinar aos moradores os princípios de higiene que eram

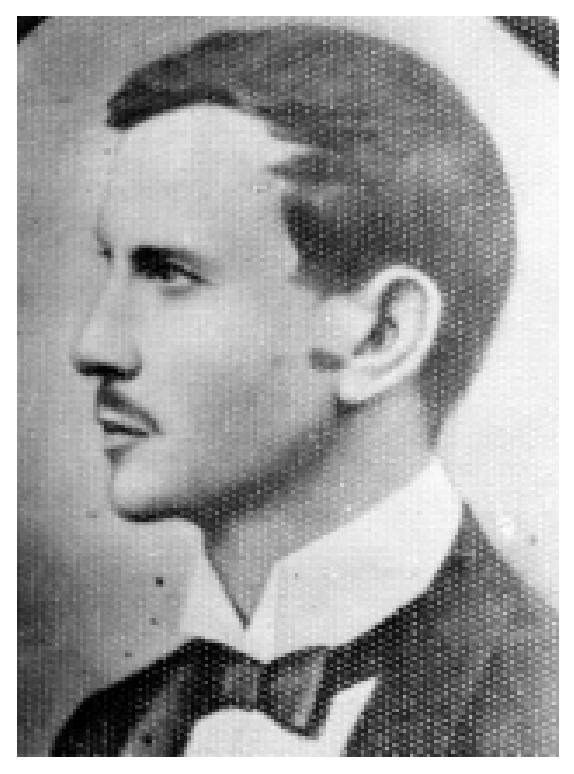

Georg Carl Adolf Bleyer (1867-1955). 
veiculados pelos tratados europeus da época, incorporando já a preocupação com a transmissão de germes pelo ar, água e outros meios vivos ou inanimados. Insistentemente, exortava seus pacientes e concidadãos a não poluírem as águas e a não devastarem a flora nativa, que considerava essencial à purificação do ar. Alertava para o perigo que representava a construção de estábulos e chiqueiros perto das residências e fontes de águas. Aconselhava que removessem para fossas profundas os monturos que exalavam mau cheiro e poeiras mefíticas.

Bleyer (1905, pp. 78, 79) divergia do viés autoritário que caracterizava o discurso dos higienistas brasileiros e europeus na implementação de medidas desta natureza. Ao comentar o projeto apresentado à Câmara Municipal de São Paulo pelo vereador José Osvaldo, declarou:

é justo esperar plena correspondência aos excelentes intuitos que produziram a aceitação destas medidas especiais, dignas de imitação por parte de outras municipalidades, para o bem geral da coletividade. Cumpre entretanto às autoridades incumbidas de pôr em prática estas medidas a obrigação de que usem de todos os meios suasórios e brandos que convencem, a fim de que não seja aceita antipaticamente a execução destes meios profiláticos que a higiene moderna necessita reclamar. ${ }^{2}$

Em 1905, por sua influência, a Câmara Municipal de Curitiba legislou sobre a remodelação dos açougues da cidade, determinando que as carnes fossem cobertas "com um tecido de arame ou outro qualquer, a fim de evitar o contato com as moscas".

Bleyer estava em sintonia com os trabalhos que vinham sendo publicados no Brasil e no exterior a respeito do papel dos insetos como hospedeiros de microrganismos e transmissores de doenças. De quando em vez fazia viagens ao Rio de Janeiro para consultar livros e periódicos nas bibliotecas da Faculdade de Medicina e do Instituto Oswaldo Cruz (IOC), e para visitar os laboratórios deste Instituto e do Museu Nacional. Consta, inclusive, que a pedido de Adolpho Lutz e de outros cientistas de Manguinhos, Bleyer trazia espécimes zoológicos e micróbios, estes cuidadosamente preservados em tubos com gelose ( $O$ Imparcial, 18.7.1899).

Em Brusque, testemunhou a morte de uma mulher em conseqüência da destruição dos olhos por larvas de moscas. Registrou o caso no periódico do Institut für Schiffs und Tropenkrankheiten (atual Berhard-Nocht Institut für Tropenmedicin), em Hamburgo (Bleyer, 1900). Publicou, também, em Curitiba, importante trabalho

\footnotetext{
${ }^{2}$ Em O Imparcial (9.4.1904) lê-se que "em obra recentemente publicada pelo sábio universalmente conhecido, dr. Scheube, encontram-se referências sobremodo honrosas ao dr. Bleyer, proclamandoo como um infatigável lutador na ciência bacteriológica".
} 
sobre a miíase (Bleyer, 1905), doença humana e animal vulgarmente chamada de bicheira, transmitida por mutucas (tabanídeos), um dos grupos que Adolpho Lutz investigou com mais afinco. Graças a este trabalho, Bleyer foi eleito membro correspondente da Academia Nacional de Medicina, no Rio de Janeiro em, 15 de setembro de $1905 .^{3}$

Um exemplar de O Correio Lageano, de 1907, traz uma coluna escrita por ele com o título 'Campanha Sanitária'. Orientava a população sobre as medidas para prevenção de diversas doenças, especialmente a lepra. Afirmava que, embora os índices de morbidade não fossem elevados, havia focos perigosos espalhando bacilos de Hansen em Lajes, Tubarão, Palhoça, Tijucas, Mafra, Porto União, Laguna e na própria capital do estado, o que requeria o isolamento dos doentes em leprosários ou outros lugares apropriados. Embora endossasse o ponto de vista contagionista, então hegemônico, Bleyer, à semelhança de Adolpho Lutz e, talvez, influenciado por ele, nutria a convicção de que a doença podia ser transmitida por algum inseto hospedeiro.

Os parasitas naturais do homem ou de animais domésticos, pulgas, percevejos, vermes (Ancylostoma, Necator, Ascaris, Oxyuris etc.) eliminados com as fezes, mosquitos, moscas, a própria mosca doméstica, pousando sobre escarros ou secreção patológica, dejeções, excretos de um leproso, podem, sob circunstâncias favoráveis, transmitir o mal e propagar os germes da moléstia para as casas vizinhas e seus inquilinos. ... O corpo humano tem a sua defesa orgânica natural. Depende quase sempre, a aquisição da lepra, de um enfraquecimento orgânico, de um desequilíbrio da constituição celular coloidal, de uma enfermidade enfim, para inserir-se no organismo o germe da doença, sendo às vezes lenta a sua evolução antes de apresentar a sintomatologia mórbida característica com deformações do rosto, dos pés, das mãos e de ulcerações visíveis no corpo.

Bleyer (1919) foi o primeiro a descobrir a doença de Chagas em Santa Catarina. Enviou a Carlos Chagas o estudo que escreveu sobre o assunto, junto com exemplares do barbeiro, o inseto hematófago que hospedava e transmitia o tripanossoma que causa a doença (ver também Castro, 1978).

Em 1919, quando se iniciava a reforma da saúde pública e a criação do Departamento Nacional de Saúde Pública, sob a liderança de Chagas, Bleyer elaborou o regulamento sanitário que regeria as ações da Inspetoria de Higiene de seu estado. Dois anos depois, foi chamado a pô-lo em prática, e a enfrentar focos de varíola e outras doenças

${ }^{3}$ O trabalho teve grande repercussão em Santa Catarina (Correio do Povo, 23.3.1905, p. 1; O Imparcial, 12.3.1905). Em carta datada de 26.5.1931, Eurico Villela, do Instituto Oswaldo Cruz, pediu a Bleyer, para a biblioteca da instituição, cópia dos trabalhos que "os drs. Lutz e Costa Lima ... indicaram-me como as mais completas sobre as moscas miíases". 
infecciosas, como a febre tifóide, como já havia feito com a célebre gripe espanhola, que tantas vidas ceifou no Brasil. No município de São Joaquim, sob a sua supervisão, esta produziu taxa de óbitos de aproximadamente 1\% (Ofício de 10.3.1919).

Nos arquivos da família há vários documentos de prefeituras municipais, autoridades e amigos elogiando a atuação de Bleyer como médico, higienista e autoridade sanitária em Santa Catarina. Encontram-se, também, ofícios do Corpo de Segurança do Comando da Cavalaria do Exército (Lajes), do Destacamento do Exército sediado em Campos Novos e dos Destacamentos da Força Pública de Florianópolis, Chapecó e São Joaquim.

A ligação de Bleyer com as forças armadas remonta à Revolução Federalista (1893-95), no governo do marechal Floriano Peixoto, quando se engajou como oficial médico das tropas de linha (Cabral, 1973, p. 313). Saiu ileso das sangrentas batalhas.

Em memorial dirigido ao presidente Getúlio Vargas, em 18 de julho de 1931, as autoridades de São Joaquim pediram que fossem concedidas ao dr. Bleyer as honras de médico militar do Exército, pelos relevantes serviços profissionais prestados àquele município catarinense nos tempos difíceis que antecederam a Revolução de 1930, quando São Joaquim foi tomado pelas forças de Leonel Rocha.

$\mathrm{Na}$ qualidade de representante da Cruz Vermelha Internacional e de Delegué Honoré de la Association Médicale pour aider à la Supression de la Guerre, Bleyer visitou o comandante das forças rebeldes com o objetivo de afastar os revoltosos da cidade e restituir valores saqueados de moradores pobres.

Interessou-se também pelos problemas dos presidiários, tendo aconselhado a remodelação das prisões, nas quais chegou a fazer cirurgias de urgência.

Agiu como pacificador quando elementos da polícia foram enviados a São Joaquim para combater o levante do Partido Liberal, apondo-se a várias tentativas de assassinato de líderes liberais.

\section{Pesquisas científicas em aldeamentos indígenas}

Bleyer teve atuação marcante em relação às populações indígenas. Em 1903, visitou a aldeia dos kaingang, em Palmas, no estado do Paraná, para investigar, a pedido de Karl Van Den Steinen, a origem daqueles indígenas. Tão entusiasmado ficou com os resultados obtidos nos cinco meses que lá permaneceu, que voltou a Lajes para buscar a mulher grávida e os filhos e se transferiu para Palmas (O Imparcial, 1904). Foi nesta vila que a família sofreu o primeiro revés: o falecimento de Alzira, a filha recém-nascida, vitimada por uma infecção. Os parcos recursos de então, a grande distância entre o aldeamento dos índios e a cidade (mais de $60 \mathrm{~km}$ de estradas íngremes) não permitiram que o pai soubesse a tempo da doença da filha. 
Ao chegar ao aldeamento dos índios kaingang, denominado Antas, às margens do rio Chapecó, a cerca de dez léguas da cidade de Palmas, Bleyer encontrou seus habitantes às voltas com uma epidemia que já havia dizimado trinta homens, seis mulheres e quatro crianças (O Imparcial, 1904). Graças aos cuidados que dispensou a todos, conseguiu salvar os demais doentes, conquistando assim a gratidão daquela gente que o chamava de "enviado da providência", como assinalou o Der Kompas, de Curitiba.

A permanência de Bleyer entre os kaingang prendia-se a uma finalidade científica bem determinada: observar se aqueles indígenas traziam, ao nascer, a larga mancha azulada que o dr. Baelz, médico conselheiro da corte do Japão, encontrara em 1901 em todo malaio, chim ou japonês (O Imparcial, 30.4.1904; 7.5.1904). Essa mancha desaparecia somente no terceiro ou quarto ano de existência. Para Baelz, era um sinal ainda não observado por outros médicos e antropólogos que singularizava a raça mongólica e poderia, talvez, ser identificado nos índios das Américas, o que atestaria sua origem mongólica. A escola monogenista atribuía o povoamento das Américas a migrações seculares de povos de continentes mais antigos que teriam alcançado o Alasca e o restante do continente através do estreito de Bering. Baseando-se nesta teoria, hoje comprovada, Baelz sugeriu a investigação da presença daquelas manchas características nas crianças indígenas da América em nota publicada no Zeitschrift fürEthnologie, em 1901, por iniciativa da Sociedade Antropológica de Berlim.

Bleyer realmente encontrou o sinal perfeitamente visível nas crianças que examinou, confirmando a possibilidade enunciada por Baelz. Publicou então 'Die blauen flecken der Mongolenkinder bei Kindern SudAmerikannischer Indianer beobachtet' (As manchas azuladas das crianças mongóis observadas nas crianças indígenas da América do Sul).

As observações de Bleyer sobre as doenças que flagelavam a população indígena são de grande valor. Publicou-as na revista Archiv für Schiffs und Tropenhygiene (1923) e Zeitschrift fur Ethnologie (1905): 'Aerztliche notizen aine Reise Zu Den Caingang — indianer na den ufern des Chapecó'.

Das pesquisas realizadas por Bleyer entre os indígenas botocudos, ou "Schokléng", originou-se a obra Die wilden Waldindianer Santha Catharina: die Schokléng (1904), que apresentou à Sociedade Antropológica de Berlim, da qual era membro, por intermédio de Karl Van Den Steinen, que prefaciou aquele trabalho e considerou-o um dos mais completos sobre o assunto (O Imparcial, 1905). No último parágrafo do trabalho sobre aqueles índigenas outrora dominantes entre as tribos das selvas da costa marítima do Sul do Brasil, Bleyer escreveu: "Estes índios necessitam da paz, porém para a nação guerreira dos Schokléng a paz, verossimilmente, só reinará quando o último destes índios das selvas de Santa Catarina desaparecer e já não puder vingar-se." 
CAMINHOS PERCORRIDOS PELO DR. JORGE CLARKE BLEYER

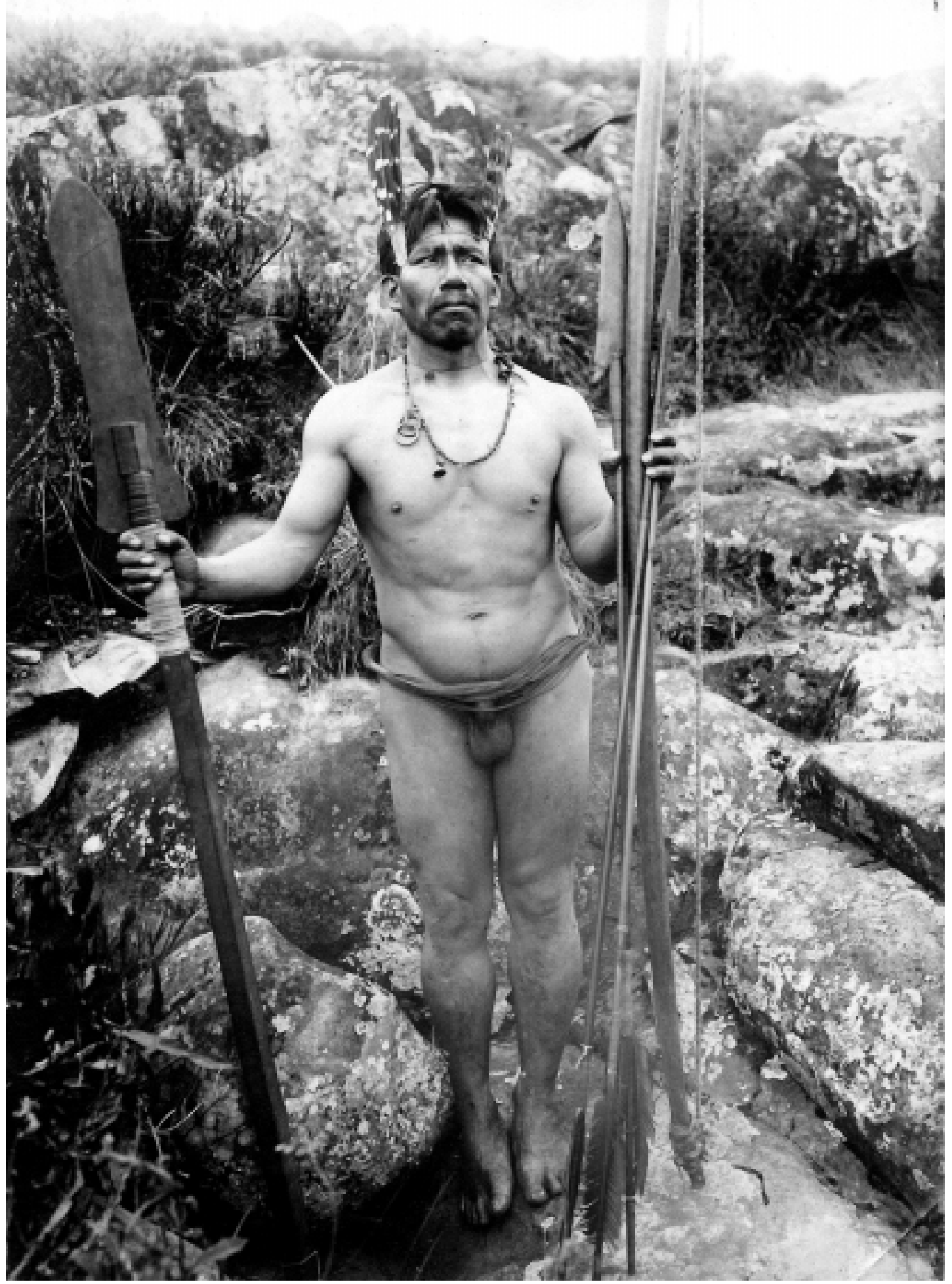

Índio botocudo ou Schokléng. 
Bleyer assumiu posições corajosas em defesa dos indígenas, que eram alvo de políticas genocidas por parte dos agentes da expansão do capitalismo no Brasil. Por muitos anos, correspondeu-se com o marechal Rondon, que era seu amigo, correspondência que prosseguiu em prol da mesma causa com os diretores do Serviço de Proteção ao Índio. ${ }^{4}$ Entre os trabalhos manuscritos deixados por ele, encontra-se a seguinte nota de leitura:

Capitão-tenente Lucas Bioteaux, História catarinense, 1905 - Como nossos silvícolas continuassem a cometer tropelias em vários pontos, ordenou o governador a organização de turmas de batedores do mato, para afugentá-los. Tão desumanamente se portaram as tais turmas sinistras, que fuzilaram desapiedadamente 145 botocudos entre adultos e crianças, e como troféu de sua campanha assassina trouxeram para a capital dez inocentes, que o governador, penalizado, fez entrega ao Asilo de Órfãos São Vicente de Paula. Essas míseras crianças, arrancadas ao carinho dos seus, vieram todas a falecer...

As ferrovias e linhas telegráficas expandiam-se pelo território nacional. Bleyer foi convidado a integrar a comissão médica da Estrada de ferro São Paulo-Rio Grande do Sul, da Brazil Railway Co. e Brazil Development \& Colonization Co., função que exerceu de 1905 a 1908.

No curso de anos dirigindo comissões sanitárias no tempo de endemias, febres do grupo tifóide, de varíola, de septicemia carbunculosa, como médico da Divisão Sul da Companhia Brazil Railway — Estrada de Ferro São Paulo-Rio Grande do Sul tive muitas vezes ... ocasião de estudar os usos, costumes, correrias e as tristezas de agrupamentos remanescentes de tribos (Arquivo Bleyer, 1948).

Em cada localidade em que residiu, Bleyer empreendeu investigações antropológicas interessantes e valiosas. No município de São Joaquim, em 1914, fez, com seus próprios recursos, custosas viagens com o objetivo de obter evidências que ajudassem a esclarecer a controvertida questão da origem do homem no Brasil. Embrenhou-se nas matas, percorreu serras, visitou grutas, acompanhado apenas de alguns auxiliares para ajudá-lo nas escavações. Encontrou vários espécimes que julgou terem pertencido a época geológica muito remota. Pretendia demonstrar que há milhares de anos vivera no Brasil o homem das cavernas, com costumes similares aos dos trogloditas da era quaternária.

\footnotetext{
${ }^{4}$ Em carta dirigida ao dr. Modesto Donatini Dias da Cruz, diretor do Serviço de Proteção ao Índio (SPI), em 8 de janeiro de 1948, Bleyer agradeceu "a delicada atenção da remessa de duas monografias: atividades do Serviço de Proteção ao Índio e comentários do diretor do Serviço de Proteção ao Índio. Li as publicações com sumo interesse; falam sobremaneira à minha alma e ao meu coração as suas palavras: "Tomei a mim um dever para com a pátria — o de proteger seus filhos mais desamparados."”
} 
Um de seus achados foi uma calota craniana humana junto a resíduos de festins canibais, totalmente mineralizada e com sinais de golpes brutais que haviam separado a epífise da diáfise. Encontrou também um crânio de fronte esbatida parecido com o tipo neandertalóide e muito semelhante à calota encontrada na serra do Uruburetama, Ceará, pelo dr. Lund. O crânio foi doado por Bleyer ao Museu Nacional e lá se encontra até hoje.

Em sessão da Academia Nacional de Medicina, à qual compareceu o padre A. Deiber, de Paris, renomado egiptólogo e arqueólogo francês, expôs farto material encontrado em suas expedições por Santa Catarina, peças paleontropológicas humanas fossilizadas e diversos artefatos singulares, arqueolíticos e paleolíticos, todos considerados de grande valor científico à época.

Peças recolhidas por Bleyer foram enviadas ao Museu Nacional do Rio de Janeiro, ao Natural History Museum de Londres, ao Provinzial Museum de Hannover, à Escola Real de Medicina de Dublin, Irlanda, e a outras instituições médicas ou arqueológicas européias (Piazza, 1966, 11-2). Bleyer correspondeu-se com o antropólogo e médico Arthur Keith, que foi o relator do estudo por ele apresentado ao Congresso Internacional de Americanistas, em Londres, em 1912, sobre antropofagia entre os habitantes pré-históricos do planalto de Santa Catarina.

De Bertha Lutz, filha de seu amigo Adolpho Lutz, recebeu cartas relativas a esses estudos antropológicos, que a ela muito interessavam também. No Congresso Internacional de Americanistas, realizado no Rio de Janeiro, em 1922, Bleyer (1928, pp. 16-23) apresentou 'Investigações sobre o homem pré-histórico, habitante de grutas e abrigos sob as rochas'. Muitas das investigações que realizou ulteriormente, entre 1915 e 1937, permanecem inéditas.

Evolucionista, Bleyer endossava as conclusões a que haviam chegado, no Brasil, os drs. João Batista de Lacerda e Afrânio Peixoto sobre a origem do homem americano: a América havia sido um dos centros da criação, e mais tarde povos emigrados da Ásia ou de outros pontos do globo vieram fundir-se com a raça primitiva, produzindo a atual, com suas infinitas subdivisões. Num livro de Lacerda, de quem era amigo, Bleyer assinalou um trecho que expressava idéias em que ele também acreditava:

no ponto de vista da evolução social e política a América ainda é um embrião: ela vai evoluir, ao que parece, de conformidade com as leis do transformismo, caminhando lentamente até encarnar um tipo social, que figure o mais adiantado grau da perfeição humana em confronto com os tipos já constituídos. Aqui, neste continente, se dará a solução dos grandes problemas do futuro, pela ação combinada das duas raças - uma que já foi a dominadora do mundo, em um longo período histórico, outra que assumiu a preeminência incontestada entre os povos modernos. Por uma exaltação de certas qualidades, que a história natural dos cruzamentos tem demonstrado, 
Registro meus agradecimentos à profa. Mary Karash, sob cuja orientação realizei esta nota de pesquisa, na da Universidade de Brasília Estendo-os ao Ministério da Educação e Cultura, à Fundação Milton Campos, à Embaixada da República Federal da Alemanha, ao sr. Danilo de Castro, proprietário do Museu Thiago de Castro, às minhas tias e ao prof. Walter Piazza, da Universidade Federal de Santa Catarina (UFSC), que contribuíram com informações para este estudo. o latino e o saxônico cruzando-se, hão de dar ao mundo um produto novo, dotado de alto grau das qualidades eminentes que distinguem as duas raças. O engenho brilhante e artístico do latino se aliará, nesse produto étnico americano, à energia e à perseverança, ao espírito empreendedor do saxônico (Lacerda, 1905, p. 58).

Bleyer (1913) sentia-se fascinado pelos problemas propostos à ciência pelo "extraordinário e infinito conjunto de variadas feições que tomou a raça americana, numa ascensional e muito progressiva evolução". As escavações a que dedicou boa parte de sua vida o conduziam,

através de milênios de anos e através de tantas camadas de gerações extintas, às origens do desconhecido homem troglodita, contemporâneo na noite dos tempos, do feliz protopanther (sic), do Megaterium, do mylodoro (sic), do Hydrochaerus sulcidens, do cavalo fóssil, do thama que hoje habita somente as serras nevadas das cordilheiras dos Andes.

Vivendo no interior, distante dos grandes centros científicos do Brasil e do exterior, Bleyer não se tornou conhecido no país, não obstante tenha produzido uma obra científica que estava em sintonia com os conhecimentos e controvérsias de ponta nos domínios da medicina, antropologia e etnografia. Homem perseverante, modesto, foi um infatigável pesquisador e deixou importante legado não apenas para as ciências da vida como para a instituição da saúde pública em Santa Catarina. ${ }^{5}$ Evoco, para concluir, as palavras de Pasteur, pronunciadas na Academia Francesa, para homenagear o labor e o humanismo de Littré: "A grandeza das ações humanas mede-se pela inspiração que lhes deu o ser. Feliz de quem traz em si um Deus, um ideal de beleza, e lhe obedece: ideal de arte, ideal de ciência, ideal de pátria, ideal das virtudes do Evangelho. São esses os mananciais vivos dos grandes pensamentos e das grandes ações. Todas elas, todos eles, se alumiam dos reflexos do infinito" (Barbosa, 1952, p. 135).

\footnotetext{
5 "A esse cientista deve o estado de Santa Catarina, e por conseguinte o país e também o continente americano, o muito que ele fez pela nossa etnografia e antropologia, dedicando-se de corpo e alma ao ramo da ciência por que tanto se debateu. As fadigas que tem experimentado o dr. Bleyer e as despesas de seu bolso particular que tem feito, a bem da antropologia e etnografia brasileira, bem merecem ser recompensadas, pois não é só a ciência que lucra com tais investigações, lucram também, e muito, o estado, o Brasil e a América" (Bleyer, 1922).
} 


\section{FONTES}

Arquivo da Embaixada da República Federal da Alemanha

1978

Angélica Bleyer de Meira Lima

1978

Ondina Bleyer

1978

Danilo Thiago de

Castro

1978

Bleyer

Arquivo Bleyer 1948

Arquivo da Família Bleyer

mar.-abr. 1940

Arquivo da Família Bleyer

15.7.1935

Arquivo da Família Bleyer

Arquivo da Família Bleyer

18.7.1931

Arquivo Bleyer

4.11. 1929

Arquivo Bleyer

15.5.1925

1922

12.2.1921

Arquivo Bleyer

10.3.1919
Informações sobre a família do dr. Bleyer em Hannover. Brasília.

Entrevista

Rio de Janeiro.

Entrevista. Lajes.

Entrevista. Lajes.

Entrevista.

Manuscrito de carta redigida pelo dr. Bleyer para o diretor do Serviço de Proteção ao Îndio.

Declarações dos oficiais de Registro Civil e escrivães da paz de Campos Novos e Lajes relativas à ausência de óbitos e, portanto, ao êxito das medidas tomadas pelo dr. Bleyer contra as epidemias de tifo e paratifo.

Ofícios da prefeitura municipal de Bom Retiro elogiando a atuação do dr. Jorge Clarcke Bleyer, médico residente na cidade de Lajes, durante a epidemia de tifo e paratifo que grassou na sede da comarca de janeiro a junho de 1935

Carta do dr. Eurico Villella para o dr. Bleyer. Rio de Janeiro.

Prefeitura municipal de São Joaquim da Costa da Serra.

Ofício enviado ao presidente da República Getúlio Vargas.

Ofício do comandante do Destacamento de Ocupação do Município de Campos Novos, 1925; comandante do contingente da Força Pública do estado de Santa Catarina em São Joaquim da Costa da Serra, todos agradecendo os bons serviços médicos prestados pelo dr. Bleyer.

'Falecimento de um sábio alemão, cujo nome está ligado com o Brasil (Karl Van Den Steinen)'. A Época, Lajes.

Ofício do comandante do Destacamento de Ocupação do Município de Campos Novos elogiando os serviços profissionais prestados por Bleyer.

'Dr. Bleyer'. Entrevista concedida pelo dr. Simões da Silva, presidente do Congresso Internacional de Americanistas, realizado no Rio de Janeiro.

Ofício da Superintendência Municipal de Chapecó pedindo que Bleyer tratasse da execução do regulamento sanitário em vigor e da higiene defensiva tendo em vista o aparecimento de focos de varíola e outras doenças epidêmicas na zona marítima e em portos anexos.

Carta do Britsh Museum (Natural History) ao dr. Bleyer, em 5 de maio de 1920.

Ofício do gabinete do superintendente municipal de São Joaquim, congratulando Bleyer pela diminuta mortalidade havida durante a pandemia da espanhola. 
Arquivo Bleyer Cartas do dr. Adolfo Lutz dirigidas ao dr. Bleyer em 24.5.1917, 22.6.1927,

1917-1931 30.1.1928, 29.8.1930, 15.1.1931.

Arquivo Bleyer Carta do Royal College Of Surgeons of England, remetida por Arthur Keith, em 31 de dezembro de 1914

Arquivo da Inspetoria de Certidão relativa ao registro do diploma de médico do dr. Georg Carl Adolf Saúde do Estado de Santa Catarina Bleyer no Livro de Registro de Diplomas e Títulos, p. 66.

30.12.1912

15.9.1905

Ofício da Academia Nacional de Medicina.

23.3.1905 Correio do Povo, Florianópolis, p. 1.

12.3.1905 'O perigo das moscas'. O Imparcial.

21.4.1905 'Dr. Jorge Bleyer'. O Imparcial, Lajes.

Arquivo Bleyer mar. 1905 Carta do Royal College of Surgeons in Ireland, dirigida ao dr. Bleyer.

7.5.1904 'Dr. Jorge Bleyer'. O Imparcial, Lajes.

7.5.1904 'Dr. Jorge Bleyer (da região serrana)'. O Imparcial, Lajes.

9.4.1904 'Dr. Bleyer'. O Imparcial, Lajes.

13.2.1904 'Dr. Bleyer'. O Imparcial, Lajes.

11.9.1901 'Ao ilustre dr. Jorge Bleyer'. O Imparcial.

18.7.1899 'Dr. Jorge Bleyer'. O Imparcial, Lajes.

Arquivo Bleyer 1.9.1898

Arquivo Bleyer

Sessão da Academia Nacional de Medicina 26.4.1913

Castro (1978) 7.9.1919

Ofício do comandante do Corpo de Cavalaria do Estado de Santa Catarina atestando que Jorge Bleyer prestara serviços médicos bem-sucedidos.

Manuscrito do dr. Bleyer sobre os índios.

Arquivo Público do Estado de Santa Catarina, Departamento Estadual de Estatística, Divisão de Estatística Militar, Cadastro Profissional do dr. Georg Clarke Bleyer.

Correio da Manhã, Rio de Janeiro.

'Moléstia de Chagas em Santa Catarina' República, Florianópolis.

\section{REFERÊNCIAS BIBLIOGRÁFICAS}

Barbosa, Rui

1952

Bleyer, Jorge Clarke 1928

Bleyer, J. Clarke 1923
Oswaldo Cruz.

Rio de Janeiro, Edição da Organização Simões.

'Investigações sobre o homem pré-histórico, habitante de grutas e abrigos sob as rochas. Sobre o canibalismo aborígine pré-histórico habitante de grutas e abrigos sob rocha'. Annaes do XX Congresso Internacional de Americanistas, Rio de Janeiro, 20 a 30 de agosto de 1922, organizado pelos secretários drs. Leon F. Clérot e Paulo José Pires Brandão. Rio de Janeiro, Imprensa Nacional, vol. II, primeira parte, pp. 16-23.

'Über eine merkwürdige Indianische Behandlungsweise eines Falles von Thyreoiditis parasitaria'. Archiv für Schiffs und Tropen-Hygiene, vol. 27 , p. 197-202. 
Bleyer, Jorge Clarke 1922

Bleyer, Jorge

Bleyer, Jorge 1918-19

Bleyer, George Clarke 1913

Bleyer, Jorge A. C. 1913

Bleyer, Jeorge A. C. 1909

Bleyer, George
1905

Bleyer, George C. 1905

Bleyer, George C. 1904

Bleyer, George C. 1903

Bleyer, George C. 1902

Bleyer, George C. 1901

Bleyer, George C. 1900

Bleyer, Georg 1892

Cabral, Oswaldo 1937

Lacerda, J. B. de 1905

Piazza, Walter F. 1966

Steinen, Karl von den 1942

Steinen, Karl von den 1940
'Üeber Aufreten Von Varíola unter Affen der genera Mycetes und Cebus bei Vordringen einer Pockenepidemie im Urwaldgebiete na den Nebenflüssen dês Alto Uruguay in Südbrasilien'. Sonderdruck aus der Münchener medizinischen Wochenschrift, nr. 27, s. 1009 u. 1010, 4 p.

'A nova entidade morbida, descoberta pelo dr. Carlos Chagas, a denominada 26.8.1919 moléstia de Carlos Chagas (Coreotrypanosis Chagasi), existe em diversas zonas de Santa Catharina'. República, Florianópolis, ano XIV, no 267.

'Contribuição para o estudo do troglodyta das cavernas no planalto do Brasil'. Revista do Instituto Histórico e Geográfico de Santa Catarina, Florianópolis.

'Üeber die Anthropophagie prähistorischer Ureinwohner des Hochplateau's von Santa Catharina in Brasilien'. Proceedings of the XVIII Congress of Americanists, Londres, pp. 50-3.

'Contribuição para o estudo do troglodita das cavernas no planalto do Brasil. Conferência realizada na Academia Nacional de Medicina do Rio de Janeiro (25.4.1913) pelo dr. Jorge A. C. Bleyer'. Rio de Janeiro, Boletim da Academia Nacional de Medicina.

'Ein Beitrag zum Studium brasilianischer Nesselraupen und der durch ihre Berührung auftretenden Krankheitsform beim Menschen, bestehend in einer Urticaria mit schmerzhaften Erscheinungen'. Archiv für Schiffs und Tropen-Hygiene, vol. 13, p. 73-83.

Contribuição para o estudo das moléstias tropicais e subtropicais.

Tratado de Myasis. Ensaio de um estudo clinico sobre o papel das moscas na patologia humana. Curitiba, Editores Annibal Rocha \& Cia.

'Aerztliche notizen aine Reise Zu Den Caingang — indianer na den ufern des Chapecó'. Zeitschrift fur Ethnologie, vol. 7.

'Bericht des Hern. Dr. Bleyer in Santa Catarina über die wilden Waldindianer Santa Catharina: die Schokléng' Zeitschrift für Ethnologie, vol. 6, p. 830-47. Prefácio de von den Steinen.

'Giftwirkung der Cuatiára'. Archiv für Schiffs und Tropen-Hygiene, vol. $7, \mathrm{n}^{\mathrm{o}}$, p. 205-20.

'Eine Ichthyophagin'. Archiv für Schiffs und Tropen-Hygiene, vol. 6, p. 278.

'Prof. dr. C. A. Moncorvo'. Archiv für Schiffs und Tropen-Hygiene, vol. 5 , p. 393.

'Eine Cuterebralarve im Augenlid'. Archiv für Schiffs und Tropen-Hygiene, vol. 4, p. $168-70$

'Die Brillenschlange'. Prometheus, ano III, nº 122, pp. 276-9.

Santa Catarina.

São Paulo, Editora Nacional.

Fastos do Museu Nacional.

Rio de Janeiro, Imprensa Nacional.

As grutas de São Joaquim e Urubicí. Notas de pesquisa.

Universidade Federal de Santa Catarina, Instituto de Antropologia. Série Arqueologia 1.

O Brasil central; expedição em 1884 para a exploração do rio Xingu. São Paulo, Companhia Editora Nacional.

Entre os aborígines do Brasil central. São Paulo, Departamento de Cultura. 